\title{
Ilmu Ladunni dalam Perspektif al-Ghazali
}

\author{
Agus Sutiyono \\ IAIN Walisongo Semarang \\ Email: aguszahroh@yahoo.com
}

\begin{abstract}
Science Ladunni inspiration is flowing light, which can occur after improvement (taswiyah). Rationally, all knowledge can be acquired through learning. This is key in pursuing the events and education trips. Learning becomes important when one wants to reach the succes top life in understanding the science. How to get the science ladunni according to al-Ghazali, namely; first, trying to grab all the knowledge and take the highest ration of science the most. Second, proper training (ar-riyad ash sad iqah) and supervision are valid (al-muraqabah as sahihah), and still a fraid God with truth. Third, thinking (tafakur), if the soul has learned and trained to be a science, then he bertafakur. Fourth rabbaniyah purify hearts decorated with zikrullah.
\end{abstract}

Keywords: al-Ghazali, Science ladunni.

\begin{abstract}
Abstrak
Ilmu Ladunni ialah mengalirnya cahaya ilham, yang bisa terjadi setelah penyempurnaan (taswiyah). Secara rasional, semua ilmu pengetahuan dapat diperoleh melalui belajar. Ini merupakan kunci dalam meniti peristiwa dan perjalanan pendidikan. Belajar menjadi penting Ketika seseorang ingin mencapai puncak keberhasilan hidupnya dalam memahami ilmu. Cara mendapatkan ilmu ladunni menurutt al-Ghazali yaitu; pertama, berusaha meraih semua ilmu dan mengambil jatah terbanyak dari ilmu yang paling banyak. Kedua, latihan yang benar (arriyadah as-sadiqah) dan pengawasan yang sahih (al-muraqabah as-sahihah), serta tetap merasa takut kepada Allah dengan sebenar-benarnya. Ketiga, berfikir (tafakur), apabila jiwa telah belajar dan terlatih akan suatu ilmu, kemudian ia bertafakur. Keempat mensucikan hati rabbaniyah yang dihiasi dengan żikrullah.
\end{abstract}

Kata kunci: al-Gazali, ilmu Ladunni. 


\section{A. Pendahuluan}

Manusia sebenarnya diciptakan oleh Tuhan sebagai makhluk yang sadar. Kesadaran manusia itu dapat disimpulkan dari kemampuannya berpikir, berkehendak dan merasa. Dengan pikirannya manusia mendapatkan (ilmu) pengetahuan. ${ }^{1}$ Menurut bahasa, kata ilmu adalah masdar yang maknanya sinonim dengan paham dan makrifat. Para ahli filsafat, mendefinisikan kata ilmu sebagai suatu gambaran yang dengan sifat itu orang yang mempunyainya akan menjadi jelaslah baginya sesuatu urusan. Menurut Abū Musāa al-Asy'ari, dikutip oleh Abdul Djalal, bahwa ilmu itu ialah sifat yang mewajibkan pemiliknya mampu membedakan dengan panca inderanya, sehingga tidak mungkin mengakibatkan berlawanan. ${ }^{2}$

Menurut al-Ghazali, ilmu adalah mengetahui sesuatu menurut apa adanya, dan Ilmu itu adalah sebagian dari sifat-sifat Allah. ${ }^{3}$ Al-Ghazali mengatakan dalam ar-risalah al-ladunniyah, bahwa ilmu adalah penggambaran jiwa yang berbicara (an-nafs annatiqah) dan jiwa yang tenang menghadapi hakikat berbagai hal. Seorang yang 'alim adalah samudera yang berpengetahuan dan memiliki penggambaran. Sedangkan objek ilmu adalah zat sesuatu yang ilmunya terukir dalam jiwa. ${ }^{4}$

Di dalam Islam, ilmu merupakan bagian yang integral bagi setiap pribadi manusia. Termasuk suatu kesempumaan iman seseorang apabila pelaksanaan suatu amal (perintah Allah) yang dikerjakan atas dasar ilmu. ${ }^{5}$ Dalam buku New Horizon in Muslim Education, Ali Aṣraf, dikutip oleh Noeng Muhadjir, memberikan evaluasi bahwa semua sains yang dilakukan Yunani dan Islam menggunakan pendekatan ontologis, sedangkan sains Barat menggunakan pendekatan manipulatif-manfaat.

Bangsa Barat sekarang ini lebih menekankan pada epistemologinya, menekankan pada prosedur kerja ilmiahnya. Bahwa keruntutan prosedur kerja ilmiah menentukan kebenaran yang

\footnotetext{
${ }^{1}$ Soerjono Soekanto, Sosiologi Suatu Pengantar, (Jakarta: Raja Grafindo Persada, 1999), hlm. 5

${ }^{2}$ Abdul Djalal, Ulumul Qurān, (Surabaya: Dunia Ilmu, 2000), hlm. 2.

${ }^{3}$ Al-Ghazali, Ihyā Ulūmuddìn, Juz I, (Semarang: Toha Putra, T.t.), hlm. 29.

${ }^{4}$ Al-Ghazali, Ar-Risalah al-Ladunniyyah, (Terj.) (Yogyakarta: Mitra Pustaka, 2004), hlm. 9.

${ }^{5}$ M. Bahri Ghazali, Konsep Ilmu Menurut al-Ghazali Suatu Tinjauan Psikologik Pedagogik, (Jakarta: Pedoman Ilmu Jaya, 1996), hlm. 96.
} 
dicapai. Ditinjau dari filsafat ilmu, pendekatan dominan Yunani adalah pendekatan ontologis. Islam dalam pengaruh Yunani juga menampilkan telaah substansialistik tentang ide-ide pemahamannya intuitif. Makna dibentuk berdasar keyakinan teologis dan metafisik. Sedangkan tentang IPTEK Barat ditinjau dari segi filsafat ilmu, menekankan pada pendekatan epistemologis, makna dicari lewat hubungan kausal. Makna dibentuk lewat penalaran, lewat discourse. Menurutnya, dikutip Noeng Muhadjir, bahwa orientasi IPTEK Islam diberangkatkan dari moral al- Quran, konsep IPTEK didasarkan pada ketentuan mutlak yang ditetapkan dalam al-Qur'an dan as-sunnah. IPTEK Islam bukan hanya mencari kebenaran, melainkan juga mencari kebijakan dan rida Allah. Bila demikian, maka pendekatan dominan dalam IPTEK Islam, sesuai Semangat al-Qur'an, adalah aksiologis. ${ }^{6}$

\section{B. Pembahasan}

Dalam memahami ilmu, al-Ghazali mendasarkan pemikirannya pada ajaran-ajaran agama (Islam). Oleh karena itu sebagian ahli mengatakan bahwa epistemologi al-Ghazali adalah epistemologi Islam ${ }^{7}$. Al-Ghazali menjelaskan bahwa Ilmu itu menghidupkan hati dari kebutaan, sinar penglihatan dari kegelapan dan kekuatan badan dari kelemahan yang menyampaikan hamba ke kedudukan orang-orang yang baik dan derajat yang tinggi. Memikirkan tentang ilmu itu mengimbangi puasa, mempelajarinya mengimbangi mendirikan malam, dengan ilmu Allah swt., ditaati, dengannya Dia ditauhidkan, dimuliakan, dengannya hamba menjadi wara dengannya sanak kerabat disambung, dengannya diketahui halal dan haram. Ilmu itu pemimpin sedangkan amal adalah pengikutnya orang-orang yang berbahagia itu diberi ilham mengenai ilmu dan orang-orang yang celaka itu terhalang. ${ }^{8}$

Al-Ghazali juga menerangkan bahwa ilmu itu adalah keutamaan pada Dzat-Nya secara mutlak tanpa dibandingkan, karena ilmu itu adalah sifat kesempurnaan Allah yang maha suci. ${ }^{9}$ AlGhazali Ketika membahas ilmu lebih tampak menggambarkan ta-

${ }^{6}$ Noeng Muhadjir, Filsafat Ilmu Positivisme, PostPositivisme, dan Post Modemisme, (Yogyakarta: Rakesarasin, 2001), hlm. 66-67.

${ }^{7}$ Muhadjir, Filsafat Ilmu Positivisme ..., hlm. 72.

${ }^{8}$ Al-Ghazali, Ihyā Ulümuddìn, hlm. 12-13.

${ }^{9}$ Al-Ghazali, Ihyyā Ulümuddìn, hlm. 132. 
tanan sosial masyarakat, dalam Pengertian bahwa suatu ilmu atau profesi tertentu diperlukan untuk melaksanakan kegiatan-kegiatan yang diwajibkan dalam tatanan tersebut. ${ }^{10}$ Untuk lebih jelasnya ilmu menurut al-Ghazali dapat diklasifikasikan sebagai berikut:

1. Secara Epistemologis

Secara epistemologis, ilmu terbagi menjadi dua: syari'ah dan ghairu syari'ah. Ilmu syariah ialah ilmu yang diperoleh dari para Nabi dan tidak ditunjukkan oleh akal manusia kepadanya. ${ }^{11}$ Menurut al-Ghazali, ilmu-ilmu itu seluruhnya terpuji. Ilmu itu mempunyai pokok-pokok, cabang-cabang, pendahuluan-pendahuluan dan penyempurna-penyempurna, yaitu:

a. Pokok-pokoknya itu ada empat, yaitu: Kitabullah, Sunnah rasul-Nya, ijma' ummat dan atsarsahabat. Ijma' itu pokok dari segi bahwa itu menunjuk atas sunnah. Ijma' adalah pokok dalam tingkatan ketiga. Demikian juga atsar, maka itu juga menunjuk atas sunnah karena para sahabat itu menyaksikan wahyu dan penurunannya, mereka dengan karinah-karinah keadaan dapat mengetahui apa yang gaib (tidak diketahui) oleh selain mereka. Barangkali kalimat tersebut tidak cukup untuk mengungkapkan apa yang diketahui dengan karinah-karinah.

b. Cabang (furu') yaitu sesuatu yang difahami dari pokokpokok ini, bukan dengan kepastian lafal-lafalnya tetapi dengan Pengertian-Pengertian yang diketahui oleh akal. Oleh sebab itu meluaslah pemahaman itu sehingga dari lafal itu difahami oleh apa yang dilafalkan oleh lainnya. Ini terbagi menjadi dua macam, yaitu:

Pertama, berkaitan dengan kemaslahatan-kemaslahatan dunia dan itu termuat dalam kitab fikih dan yang bertanggung jawab adalah para fuqaha. Mereka itulah ulama dunia. Kedua, sesuatu yang berkaitan dengan kemaslahatan-kemaslahatan akhirat. Yaitu ilmu mengenai keadaan hati dan akhlak yang terpuji dan tercela, sesuatu yang diridhai di sisi Allah Ta'ala dan sesuatu yang dibenciNya.

.${ }^{10}$ Abidin Ibnu Rusn, Pemikiran al-Ghazali Tentang Pendidikan, (Yogyakarta: Pustaka Pelajar, 1998), hlm. 44.

${ }^{11}$ Rusn, Pemikiran al-Ghazali ..., hlm. 44. 
Ketiga, muqaddimah yaitu ilmu-ilmu yang berlaku sebagai alat seperti ilmu bahasa dan tata bahasa karena keduanya itu merupakan alat bagi ilmu (al-Qur'an) dan sunnah Nabi saw. Bahasa dan tata bahasa itu bukanlah termasuk ke dalam golongan ilmu-ilmu sari'at itu sendiri, tetapi mendalami keduanya disebabkan syara' karena syari'at ini datang dengan bahasa Arab. Setiap syari'at tidak jelas kecuali dengan bahasa, maka menjadilah bahasa itu sebagai alat.

c. Penyempurna-penyempurna, yaitu mengenai ilmu alQur'an. Terbagi kepadasesuatu yang berkaitan dengan lafal seperti belajar qira'at (bacaan al-Qur'an) dan makhrajmakhraj huruf, kepada sesuatu yang berkaitan dengan makna seperti tafsir, karena bersandarnya juga kepada naql, karena bahasa semata tidak dapat berdiri sendiri. Kepada sesuatu yang berkaitan dengan hukum-hukumnya seperti mengetahui nasikh dan mansukh, 'am dan khas, nas dan zahir, dan cara mempergunakan sebagian dengan sebagian yang lain, itulah ilmu yang disebut usul fiqh, dan juga menggarap sunnah.

Adapun penyempurna dalam atsar dan hadis maka ilmu mengenai rijal al-hadits (periwayat hadis), nama dan nasab (keturunan) mereka, nama sahabat dan sifat-sifat mereka, mengetahui keadilan rawi dan keadaan mereka untuk membedakan yang lemah dari yang kuat, dan mengetahui umur mereka untuk membedakan mursal dari musnad. Demikian juga sesuatu yang berkaitan dengannya. $^{12}$ Adapun ilmu gairu syar'iyahatau ilmu aqliyah adalah ilmu yang bersumber dari akal, baik yang diperoleh secara ḍarurimaupun ihtisab. Duluri ialah yang diperoleh dari insting akal itu sendiri tanpa melalui taklid atau indera, dari mana dan bagaimana datangnya manusia tidak mengetahuinya. Sedangkan ihtisab ialah mencari faidah ilmu melalui kegiatan belajar dan mencari argumenargumen.

\footnotetext{
${ }^{12}$ Al-Ghazali, Ihyā̄ Ulūmuddìn, hlm. 17-18.
} 


\section{Secara Ontologis}

Berhubungan dengan tugas dan tujuan hidup manusia, alGhazali menguraikan ilmu melalui pendekatan ontologis, membicarakan sifat-sifat dasar dan aneka ragam ilmu itu sendiri. ${ }^{13}$ Secara ontologis, al-Ghazali membagi ilmu menjadi dua macam:

a. Ilmu fardu 'ain, yakni ilmu yang dibutuhkan untuk melaksanakan tugas-tugas akhirat dengan baik. Ilmu ini terdiri atas: ilmu tauhid, ilmu syari'at dan ilmu sirri. Menurut alGhazali ilmu fardu 'ain,yaitu ilmu tentang cara-cara melaksanakan amal yang wajib. Barang siapa yang telah mengetahui perbuatan yang wajib beserta waktu untuk mengerjakannya, berarti ia telah mengetahui ilmu yang termasuk ke dalam jenis fardu 'ain. ${ }^{14}$ Manusia berbeda pendapat yang menjadi fardu atas setiap muslim. Mereka berkelompok-kelompok menjadi lebih dari pada dua puluh golongan. Setiap golongan menempatkan wajib atas ilmu yang menjadi kecenderungannya.

b. Ilmu farḍu kifayah, yakni ilmu-ilmu yang berkaitan dengan urusan keduniaan, yang perlu diketahui manusia. Ilmu-ilmu ini berhubungan dengan profesi manusia, oleh karena itu tidak setiap manusia dituntut memiliki semua jenis yang ada, tetapi cukup dikembangkan melalui orangorang tertentu yang telah memiliki kemampuankemampuan khusus untuk mewujudkan kehidupan dunia ini. ${ }^{15}$ Menurut al-Ghazali fardu kifayahialah setiap ilmu yang tidak dapat tidak dibutuhkan dalam menegakkan urusan-urusan dunia seperti kedokteran karena kedokteran itu suatu kepastian (daruri) dalam kebutuhan menjaga kekalnya tubuh. Seperti berhitung karena itu pasti dibutuhkan dalam pergaulan, membagi wasiat, warisan dan Iain-lain. Inilah ilmu-ilmu yang seandainya suatu negeri tidak ada orang yang menegakkannya maka penduduk negeri itu berdosa. Apabila seorang menegakkannya maka cukuplah dan gugurlah farḍu kifayahitu.

\footnotetext{
${ }^{13}$ Rusn, Pemikiran al-Ghazali ..., hlm. 46.

${ }^{14}$ Al-Ghazali, Ihyā Ulümuddìn, hlm. 16.

${ }^{15}$ Rusn, Pemikiran al-Ghazali ..., hlm. 47.
} 


\section{Secara Aksiologis}

Selanjutnya al-Ghazali menggunakan pendekatan aksiologis dalam menilai jenis ilmu. ${ }^{16}$ Ilmu-ilmu syari'ah bersifat terpuji secara keseluruhan. Sedangkan ilmu gairu syar'iyah, ada yang terpuji, ada yang tercela, dan ada pula yang mubah. Artinya, dalam keadaan tertentu terpuji, tetapi dalam keadaan yang lain tercela atau mubah. Al-Ghazali mengatakan, bahwa ilmu itu sendiri tidaklah tercela. Ilmu itu tercela dalam hak hamba, karena salah satu dari tiga buah sebab, yaitu: Pertama, ilmu itu menyampaikan kepada kemadharatan (bahaya). Adakalanya bagi pemiliknya atau orang-orang lain seperti tercelanya ilmu sihir dan tenung. Kedua, Ilmu itu adalah membahayakan pemiliknya pada umumnya seperti ilmu nujum ${ }^{17}$. Ketiga, terjun ke dalam ilmu tidak memberi faedah kepada orang itu sendiri dari ilmunya. Ilmu semacam ini tercela bagi orang itu. Seperti dipelajarinya ilmu yang tidak jelas sebelum mempelajari ilmu yang lebih penting dan lebih jelas, menggali ilmu yang serba rahasia sebelum mempelajari ilmu yang telah teruji dan menelaah rahasia ketuhanan. ${ }^{18}$

Al-Ghazali meletakkan suatu pemahamannya tentang hakikat ilmu dalam bentuk kesatuan teoritik, yakni menjurus pada pemahaman ilmu sebagai ilmu Allah yang harus dituntut dan dikaji oleh setiap pribadi dalam upaya membawa dunia dan seisinya ke gerbang kemaslahatan. ${ }^{19}$ Menurut al-Ghazali, ilmu adalah pangkal dari segala perbuatan, oleh sebab itu maka ilmu dan ibadah adalah dua mata rantai yang saling berkait, karena pada dasarnya segala yang kamu lihat, kamu dengar dari beberapa karangan, dari pengajaran guru, dan dari hasil perenungan adalah untuk ilmu dan ibadah. ${ }^{20}$

Al-Ghazali juga mengakui keberadaan (eksistensi) indra dan akal, akan tetapi kedua instrumen insaniyah itu sangat terbatas daya capainya dan tidak mampu menjelaskan kebenaran itu secara hakiki. Bagi al-Ghazali kebenaran itu bukan hanya terbatas pada kebenaran indrawi (konkret), tetapi

\footnotetext{
${ }^{16}$ Rusn, Pemikiran al-Ghazali ..., hlm. 48.

${ }^{17}$ Al-Ghazali, Ihyā Ulümuddìn, hlm. 29.

${ }^{18}$ Al-Ghazali, Ihyā Ulümuddìn, hlm. 31.

${ }^{19}$ Ghazali, Konsep Ilmu ..., hlm. 75.

${ }^{20}$ Al-Ghazali, Manhaj al-'Abidin, (Semarang: Toha Putra, T.t.), hlm. 6.
} 
dibalik kebenaran yang nyata itu terselip suatu kebenaran abstrak yang nyata pula adanya.

Kebenaran konkret adalah kebenaran yang dapat dipantau melalui pancaindra, dapat dilihat, dirasa, didengar bahkan juga dicerna dengan akal pikiran. Kebenaran itu disebutnya kebenaran (pengetahuan) mu'amalah'. Kebenaran abstrak berada di alam ide, transendent dan nyata adanya, ia disebut pengetahuan "mukasyafah". Pengetahuan ini sulit ditembus dengan kata-kata, tidak dapat diungkapkan dengan pembicaraan, tidak mampu inderawi menjamahnya dan tidak kuasa akal meluluskannya.

Al-Qur'an dan hadis adalah jalan (tariqoh) untuk memahaminya. Karena mukasyafah merupakan kebenaran yang bersifat vertikal, dari langit dan bermuara langsung pada Allah. ${ }^{21}$ Dengan demikian ilmu itu hanya mampu dibuka dengan kunci dan jalan yang dibentangkan oleh Allah untuk sampai kepada tingkat mukasyafah itu. Di wilayah mukasyafah terletak kepercayaan, sebab kepercayaan tidaklah semata-mata berdasarkan penelitian, melainkan umumnya terjadi karena bisikan, kekuatan hati yang datangnya bukan dari manusia tetapi ia berasal dari kekuatan maha pencipta dalam bentuk 'ilham'. Ilham merupakan pengetahuan yang diperoleh dalam kebangkitan, ia merupakan pengungkapan kepada manusia pribadi yang disampaikan kepadanya oleh Allah pemilik ilmu itu melalui batinnya. ${ }^{22}$

Imam al-Ghazali menyatakan, dikutip A. Busyairi Harits, bahwa ilmu yang dihasilkan melalui ilham dinamakan ilmu Ladunni. ${ }^{23}$ Ilmu Ladunni menurutnya ialah mengalirnya cahaya ilham, terjadi setelah taswiyah (penyempurnaan). ${ }^{24}$ Ilmu itu memiliki tingkatan-tingkatan yang berbeda akibat perbedaan tingkatan manusia. Ilmu paling tinggi adalah ilmu yang muncul dari wahyu langit atau ilmu ladunni pada keadaan dekat dengan Allah. ${ }^{25}$

${ }^{21}$ Ghazali, Konsep Ilmu..., hlm. 72-73.

${ }^{22}$ Ghazali, Konsep Ilmu ..., hlm. 73.

${ }^{23}$ Busyairi Harits, Ilmu Ladunni dalam Perspektif Teori Belajar Modern, (Yogyakarta: Pustaka Pelajar, 2004), hlm. 2.

${ }^{24}$ Al-Ghazali, ar-Risalah al-Ladunniyyah, hlm. 93.

${ }^{25}$ Fu'ad Farid Isma'il dan Abdul Hamid Mutawalli, Mabādi al-Falșafah wa al-Akhlaq, (Terj.) (Yogyakarta: Ircisod, 2003), hlm. 252. 


\section{Ilmu Ladunni dalam Pandangan al-Ghazali}

Menurut al-Ghazali, ilmu ladunni adalah mengalinya cahaya ilham, terjadi setelah taswiyah (penyempurnaan) ${ }^{26}$ Untuk mendapatkan ilmu ladunni harus melalui beberapa proses sebelum sampai pada tingkat penyempurnaan. Imam al-Ghazali menggolongkan ilmu Ladunni termasuk pengajaran bersifat ketuhanan. Ia membagi dua jalan pengajaran, yaitu pemberian pelajaran melalui wahyu dan pemberian melalui ilham. Pemberian pelajaran melalui wahyu terjadi apabila hati sudah sempurna DzatNya, maka hilang tabiat yang kotor, ketamakan dan angan-angan yang sesat. Jiwa selalu menghadapkan wajahnya kepada Sang Pencipta yang menumbuhkannya. Ilmu ini biasanya diterima nabi.

Adapun pembelajaran melalui ilham adalah peringatan jiwa kulliyah (total) kepada jiwa manusia secara juz'i(sebagian), yang bersifat kemanusiaan sesuai dengan kadar kesiapan dan kekuatan penerimanya. Ilham sendiri adalah bekas wahyu. Wahyu adalah penjelasan perkara gaib, sedangkan ilham adalah bentuk samarnya. Ilmu yang diperoleh dari wahyu dinamakan ilmu nabawy, sedangkan ilmu yang diperoleh dari ilham dinamakan ilmu Ladunni.

Ilmu Ladunni adalah ilmu yang pencapaiannya tanpa perantara antara jiwa seseorang dengan Allah. Ia seperti cahaya dari lampu gaib yang jatuh ke dalam hati yang bening, bersih dan halus. Proses munculnya ilham melalui penuangan akal kully dan dari penyinaran jiwa kulliyyah. Karena itu wahyu merupakan perhiasan para nabi sedangkan ilham merupakan perhiasan para wali (kekasih Allah) ${ }^{27}$ Apabila pintu pikiran telah terbuka atas jiwa, seseorang akan mengerti bagaimana cara berpikir dan bagaimana kembali dengan ketajaman pikirannya kepada orang yang dicari. Hati menjadi lapang, mata hati menjadi terbuka, kemudian keluarlah apa yang ada di dalam hati berupa kekuatan sampai perbuatan dengan tanpa tambahan pencarian dan kesulitan.

Puncaknya, dapat dijelaskan bahwa hakikat ilmu ladunni adalah perjalanan cahaya ilham setelah kesempurnaan jiwa. Hal ini dapat dirujukkan pada tiga jalur penting. Sebagai proses untuk mencapai ilmu Ladunni, yaitu:

1. Meraih semua ilmu, dan mengambil jatah terbanyak dari ilmu yang paling banyak. ${ }^{28}$ Ini berarti bahwa al-Ghazali tidak

\footnotetext{
${ }^{26}$ Isma'il dan Mutawalli, Mabādi al-Falșafah ..., hlm. 93.

${ }^{27}$ Isma'il dan Mutawalli, Mabādi al-Falsafah ..., hlm. 38.

${ }^{28}$ Isma'il dan Mutawalli, Mabādi al-Falșafah ..., hlm. 94.
} 
menafikan adanya proses pembelajaran pada diri manusia, untuk meraih ilmu Ladunni. Tangga pertama yang harus dilalui oleh seorang yang ingin mendapatkannya adalah dengan mengoptimalkan potensi yang ada dalam diri manusia tersebut yaitu potensi akal yang diwujudkan dalam proses pembelajaran. Ladunni adalah bukan berarti meniadakan belajar, tetapi tidak melalui sebab yang biasa dilakukan manusia dengan jenjang dan tahapan belajar dalam waktu tertentu, seperti sekolah mulai dari tingkat paling rendah sampai tingkat perguruan tinggi.

2. Latihan yang benar (ar-riyadah as-Sadiqah) dan pengawasan yang sahih (al-muraqabah as-sahihah), serta tetap merasa takut kepada Allah dengan sebenar-benarnya, sebagaimana yang diisyaratkan nabi dalam sabdanya: "Barangsiapa mengamalkan ilmu yang telah diketahui, Allah akan mewariskan kepadanya ilmu yang belum ia ketahui". Ilmu identik dengan belajar, tanpa melalui proses belajar maka mustahil akan ada ilmu pengetahuan, proses belajar yang dijalankan berlangsung melalui perangkat lahir batin, fisik dan spiritual. Keduanya saling mempengaruhi dan membutuhkan perhatian yang seimbang. Dalam tahapan kedua inilah seseorang dituntut untuk latihan yang benar, maksudnya, setiap ilmu yang telah dipelajarinya dipraktikkan dalam kehidupan sehari-hari atau dengan kata lain ilmu yang telah dipelajarinya kemudian diamalkan dengan benar, sehingga ia akan memperoleh pengalaman baru hasil dari pengalamannya.

3. Tafakur (berfikir), apabila jiwa telah belajar dan terlatih akan suatu ilmu, kemudian ia bertafakur tentang gejala-gejalanya dengan sarat pemikirannya dapat membuka pintu gaib, dia seperti saudagar yang mengelola harta kekayaannya dengan syarat pengelolaan tersebut dapat membuka pintu keuntungan. Jika seorang saudagar salah jalan, ia akan terjerumus ke dalam jurang kerugian. Seorang pemikir yang menempuh jalan yang benar, akan termasuk golongan żawi al-albäb (orang-orang yang berakal). Dengan begitu, rahasia alam gaib akan jelas dipertampakkan dalam hatinya. Ia akan menjadi seorang 'alim dan seorang pemikir penerima ilham. ${ }^{29}$

Ilmu pengetahuan dibangun dalam pikiran. Setiap individu membangun sendiri pengetahuannya. Kecerdasan akal atau intelegensi merupakan puncak tertinggi setelah seseorang memiliki kua-

${ }^{29}$ Isma'il dan Mutawalli, Mabādi al-Falsafah..., hlm. 95-95. 
litas. Proses belajar dengan menggunakan pendekatan teori, percobaan, latihan dan penelitian tetap dilakukan meski pada sisi lain mengakui adanya campur tangan Tuhan terhadap manusia. kecerdasan yang diperoleh tetap dibangun di atas rutinitas belajar dengan bersungguh-sungguh dan usaha penuh kepasrahan atas kehendak Allah. Adapun cara mensucikan perbuatan-perbuatan tercela dalam rangka membersihkan jiwa, dapat ditempuh dengan empat jalan, yaitu: (1) Mensucikan diri dari najis dan hadas, (2) Mensucikan diri dari dosa lahir (maksiat) yang dilakukan panca indera, (3) Suci dari dosa batin, (4) Mensucikan hati Rabbaniyah.

\section{Penutup}

Ilmu ladunni ialah mengalirnya cahaya ilham, yang bisa terjadi setelah penyempurnaan (taswiyah). Seluruh jiwa-jiwa insani memungkinkan bagi semua ilmu.Jiwa itu mampu menampung seluruh ilmu tanpa harus ada yang ditolak, berdesakan, merasa jemu, dan menghilang. Secara rasional, semua ilmu pengetahuan dapat diperoleh melalui belajar. Ini merupakan kunci dalam meniti peristiwa dan perjalanan pendidikan. Belajar menjadi penting Ketika seseorang ingin mencapai puncak keberhasilan hidupnya dalam memahami ilmu. Proses pembelajaran yang dijalankan seseorang berlangsung melalui perangkat lahir, batin, fisik dan spiritual.

Cara mendapatkan ilmu Ladunni menurutt al-Ghazali yaitu; pertama, berusaha meraih semua ilmu dan mengambil jatah terbanyak dari ilmu yang paling banyak. Ini berarti bahwa alGhazali tidak menafikan adanya proses pembelajaran pada diri manusia, untuk meraih ilmu Ladunni. Sebab itu Ladunni adalah bukan berarti meniadakan belajar. Kedua, latihan yang benar (arriyadah as-sadiqah) dan pengawasan yang sahih (al-muraqabah assahihah), serta tetap merasa takut kepada Allah dengan sebenarbenarnya Ketiga, berfikir (tafakur), apabila jiwa telah belajar dan terlatih akan suatu ilmu, kemudian ia bertafakur. Keempat mensucikan hati rabbaniyah yang dihiasi dengan żikrullah.

\section{Kepustakaan}

Abed al-Jabiri, Muhammad, Al-Kasyfu 'An Manahij al-Adillah Fï Aqa'id al-Millah, terj. Oleh Aksin Wijaya, Yogyakarta: Ircisod, 2003. 
al-Qurtubi, Abi Abdillah Muhammad ibn Ahmad al-Anshari, alJami' Li aḥkami al-Qurān, Beirut Libanon: Dar al-Fikri, 1994.

Al-Ghazali, Ar-Risalah al-Ladunniyah, "Terj. Oleh" Khalifurrahman Fatf, Yogyakarta: Mitra Pustaka,Dunya, Sulaiman, 2002. Al Ilaqiqatu fi Nazhari al-Ghazali, Terj. Oleh Ibnu Ali, Surabaya: Pustaka Hikmah Pcrdana, 2004.

Bakker, Anton, Metode-metode Filsafat, Jakarta: Ghalia Indonesia, 1986.

Djalal, Abdul, Ulūmul Qüran, Surabaya: Dunia Ilmu, 2000.

Departemem Agama Republik Indonesia, 1994. al-Qurān dan Terjemahannya, Semarang: Kumudasmoro Grafindo,

Fu'ad Farid Isma'il dan Abdul Hamid Mutawalli, Mabadi al-Falsafah wa al-Akhlaq, Ibnu Rusn, Abidin, Pemikiran al-Ghazali Tentang Pendidikan, Yogyakarta: Pustaka Pelajar, 1998.

Ghazali, M. Bahri, Konsep Ilmu Menurut al-Ghazali Suatu Tinjauan Psikologik Pedagogik, Jakarta: Pedoman Ilmu Jaya, 1996.

Harits, A. Busyairi, Ilmu Ladunni dalam Perspektif Teori Belajar Modern, Yogyakarta: Pustaka Pelajar, 2004.

Mustansyir, Rizal dan Misnal Munir, Filsafat Ilmu, Yogyakarta: Pustaka Pelajar, 2004.

Muhajir, Noeng, Metodologi penelitian Kualitatif, Edisi IV, Yogyakarta: Rake Sarasin, 2002.

----, Filsafat Ilmu Positivisme, Postpositivisme, dan Postmodernisme, Yogyakarta: Rakesarasin. Smith, Margareth. 2000. Al-Ghazali the Mistic, Terj. Oleh Amrouni, Jakarta: Riora Cipta, 2001.

Shihab, Quraish, WawasanAt-Quran :Tafsir Maudlui Atas Pelbagai Persoalan Umat,Bandung: Mizan, 1999.

Soekanto, Soerjono, Sosiologi Suatu Pengantar, Jakarta: Raja Grafindo Persada, 1999.

Syadali, Ahmad dan Mudzakir, Filsafat Umum, Bandung: Pustaka Setia, 2004.

Walgito, Bimo, Pengantar Psikologi Umum, Yogyakarta: Yayasan Penerbitan Fakultas Psikologi UGM, 1986. 
